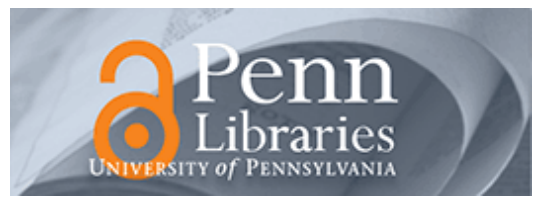

University of Pennsylvania ScholarlyCommons

April 2006

\title{
An Extreme Degree of Difficulty: The Educational Demographics of Urban Neighborhood High Schools
}

Ruth C. Nield

University of Pennsylvania

Robert Balfanz

Johns Hopkins University

Follow this and additional works at: https://repository.upenn.edu/gse_pubs

\section{Recommended Citation}

Nield, R. C., \& Balfanz, R. (2006). An Extreme Degree of Difficulty: The Educational Demographics of Urban Neighborhood High Schools. Retrieved from https://repository.upenn.edu/gse_pubs/26

Copyright Lawrence Erlbaum Associates. Postprint version. Published in Journal of Education for Students Placed at Risk, Volume 11, Issue 2, April 2006, pages 123-141.

Publisher URL: http://dx.doi.org/doi:10.1207/s15327671espr1102_1

This paper is posted at ScholarlyCommons. https://repository.upenn.edu/gse_pubs/26

For more information, please contact repository@pobox.upenn.edu. 


\title{
An Extreme Degree of Difficulty: The Educational Demographics of Urban Neighborhood High Schools
}

\begin{abstract}
Despite the growth of a variety of alternatives to the neighborhood high school, most students in big-city school systems still attend large comprehensive high schools that serve a particular residential area. The authors contend that the extreme concentration of educational need at these schools is often overlooked by policymakers, school reform programs, and even district personnel. To illustrate the challenges facing neighborhood high schools, this paper examines key academic characteristics of ninth graders in Philadelphia during 1999-00. The authors find that a large percentage of ninth graders at neighborhood high schools have been ninth graders for two or more years. Many of the first-time ninth graders are either over-age, two or more years below grade level in reading and math, or had weak attendance in eighth grade. These data suggest that large and sustained investments of human and financial capital are desperately needed in the many neighborhood schools that serve primarily, and often almost exclusively, students with multiple risk factors for academic failure.
\end{abstract}

\section{Keywords}

school demography, education needs, high risk students, attendance, academic failure

\section{Comments}

Copyright Lawrence Erlbaum Associates. Postprint version. Published in Journal of Education for Students Placed at Risk, Volume 11, Issue 2, April 2006, pages 123-141.

Publisher URL: http://dx.doi.org/doi:10.1207/s15327671espr1102_1 
An Extreme Degree of Difficulty:

The Educational Demographics of Urban Neighborhood High Schools

\author{
Ruth Curran Neild \\ Graduate School of Education \\ University of Pennsylvania \\ Robert Balfanz \\ Johns Hopkins University \\ Center for Social Organization of Schools
}

RUNNING HEAD: An Extreme Degree of Difficulty

\title{
Reprint requests:
}

Ruth Curran Neild

Assistant Professor

Graduate School of Education

University of Pennsylvania

3700 Walnut Street

Philadelphia, PA 19104 


\begin{abstract}
Despite the growth of a variety of alternatives to the neighborhood high school, most students in big-city school systems still attend large comprehensive high schools that serve a particular residential area. The authors contend that the extreme concentration of educational need at these schools is often overlooked by policymakers, school reform programs, and even district personnel. To illustrate the challenges facing neighborhood high schools, this paper examines key academic characteristics of ninth graders in Philadelphia during 1999-00. The authors find that a large percentage of ninth graders at neighborhood high schools have been ninth graders for two or more years. Many of the first-time ninth graders are either over-age, two or more years below grade level in reading and math, or had weak attendance in eighth grade. These data suggest that large and sustained investments of human and financial capital are desperately needed in the many neighborhood schools that serve primarily, and often almost exclusively, students with multiple risk factors for academic failure.
\end{abstract}


As school choice within the public sector has become more pervasive, high school students in the nation's largest cities confront an ever-widening array of schools from which they are free to choose, at least in theory (Hassell 1999; Kane 2000; Witte 2001). Nevertheless, the majority of high school students in big-city school systems attend large neighborhood schools that serve students living within specific geographic boundaries. In Philadelphia, about 70 percent of all students in non-charter public high schools are enrolled in neighborhood high schools; in Chicago, the figure is 83 percent; and in Baltimore, an estimated 67 percent attend these schools (Neild 1999; Consortium on Chicago School Research 2002; Balfanz \& Legters 2004).

It is noteworthy that so many urban students attend neighborhood high schools because these institutions are often characterized by chronic student absenteeism, high dropout rates, widespread course failure, and low academic achievement (Fine 1994). The worst school dropout rates in America cluster in urban neighborhood high schools (Balfanz \& Legters 2004). Neighborhood high schools in central cities also enroll disproportionate numbers of low-income, minority, and special needs teenagers in comparison to academically selective magnet high schools within the same district (Moore \& Davenport 1990) and are more likely to be staffed by academically under-prepared and inexperienced teachers and to experience higher teacher turnover (Chester, Offenberg, \& Xu 2001; Philadelphia Education Fund 2001). Despite the comparatively greater 
academic and social needs of their students, neighborhood high schools typically receive substantially less funding per student than those of their surrounding suburban districts (Council of Great City Schools 1998) and fewer Title I dollars per pupil than urban elementary schools (Alliance for Excellent Education 2001).

Though there has been some progress in improving achievement at urban elementary schools, until recently urban high schools have been “virtually uncharted reform territory” (Hill 2000). Policymakers, foundation program officers, and researchers have begun to pay more attention to the performance of high schools in general and specifically to those in large cities. The Gates Foundation, the Carnegie Corporation, and the Open Society Foundation, among others, have developed initiatives in support of district-wide high school reform. Several high school reform models, such as Talent Development, are attempting to address in a comprehensive manner the complex web of issues involved in reforming high-poverty high schools (Legters, Balfanz, Jordan, and McPartland 2002).

In order for these urban high school reform efforts to succeed, however, they will need to be of sufficient intensity to address the educational challenges that result from the concentration of large numbers of students with multiple risk factors for school failure in neighborhood high schools. Just as concentration of neighborhood poverty has its own negative effects on social structure and economic opportunity (Wilson 1987), the concentration of students with 
substantial educational needs in neighborhood high schools often overwhelms the capacity of the staff to respond. An understanding of the "educational demographics” of students - for example, their tested grade levels at the start of high school and the percent who have ever repeated a grade, failed courses in middle school, or received special education services - provides critical information about the type, intensity, and distribution of educational challenge faced by urban neighborhood high schools.

We contend that both past and present efforts to improve urban high schools have often lacked a deep understanding of the magnitude of the challenge associated with high-poverty neighborhood high schools. The result has been school improvement efforts that, for example, do not take into account the weak organizational infrastructure of urban schools (Riehl, Pallas \& Natriello 1999), or that introduce curricula that assume stronger academic skills than entering students actually possess, or that tackle comprehensive school reform without adequate human and financial resources to create and sustain change in urban schools.

In this paper, we look closely at key “educational demographics” of the ninth grade students who attended public neighborhood high schools in Philadelphia during the 1999-2000 school year. Two basic research questions guide our analysis: 
- First, what characteristics of students' educational backgrounds, knowable from district databases before students enter high school, predict academic trouble during the first year of high school - specifically, not earning enough credits to be promoted from ninth grade to tenth grade?

- Second, what is the concentration of students with these characteristics at the city's public high schools?

We focus on ninth graders for two reasons. By characterizing first-time ninth graders, we highlight the substantial challenges that educators at neighborhood high schools face with each new entering class. In addition, states and school districts are increasingly likely to mandate promotion requirements for ninth graders that include earning credits in specific academic courses such as Algebra 1 and/or passing end-of-course exams (Balfanz, McPartland \& Shaw 2002). Without serious attention to the challenges that ninth graders who attend urban neighborhood high schools bring with them, standards-based mandates are likely to contribute to a bottleneck in the early high school grades and to an increased dropout rate in central-city high schools (Orfield \& Kornhaber 2001). Further, ninth grade is a notoriously difficult year for urban students (Roderick 1993; Roderick and Camburn 1999). Each year in Philadelphia, for example, about 35 percent of the first-time freshmen in the public schools are not promoted to tenth grade. At some of the most troubled neighborhood high schools, between 
45 and 50 percent of the first-time freshmen are not promoted (Neild, Stoner-Eby, and Furstenberg 2001).

Our analysis uses only data from district databases to emphasize the value to school districts of maintaining and examining student data as they develop improvement strategies. For some districts, using these data may require developing a culture that appreciates and understands the data already available; for others, it may mean starting with the basics of creating an infrastructure to support the collection and maintenance of these data sets.

We first briefly analyze the student-level characteristics that increase the probability that a ninth grader will not be promoted to tenth grade, using student record data for the entire population of ninth grade students in Philadelphia during the 1998-99 school year. Next, we examine the distribution across the city's high schools of students from the subsequent cohort (those who were ninth graders in 1999-00) who have one or more of these risk factors for non-promotion. We conclude the paper with a discussion of implications for high school educators, researchers, and district, state, and federal policymakers.

\section{THE CONTEXT OF THE CITY'S NEIGHBORHOOD HIGH SCHOOLS}

The current condition of urban neighborhood high schools is largely the outcome of broader social changes that transformed urban America in the last quarter of the $20^{\text {th }}$ century. Between 1960 and 1987, the national poverty rate for 
those living in central cities rose from 13.4 to 15.7 percent, even as it fell by onehalf for rural residents and by one-third for suburban residents (Peterson 1991). By 1991, 43 percent of Americans with family incomes below the poverty line lived in central cities (Kasarda 1993). In Philadelphia, the percent of students living in a distressed neighborhood ${ }^{1}$ rose from 6 percent in 1970 to 32 percent in 1990 (City KIDS COUNT data book 1990).

Urban neighborhood high schools, serving by definition a geographically limited area, felt the full force of these economic and demographic trends as their student populations became poorer and brought with them the academic, health, and social disadvantages associated with concentration of poverty (Brooks-Gunn \& Duncan 1997). Philadelphia's magnet schools, which select students on the basis of previous academic achievement and enroll about 12 percent of the high school population in the public system, have affected somewhat the composition of the city's 22 neighborhood high schools, particularly in areas with fewer lowincome students. In the poorest neighborhoods, however, there are few students whose educational experiences enable them to meet the criteria for admission to magnet schools (Neild 2004). If students in these neighborhoods enroll someplace other than their local high school, they are more likely to attend one of the city's four vocational/technical schools or a neighborhood high school in another part of the city. 
Philadelphia is broadly representative of the large urban school districts that contain the majority of the nation's most troubled high schools (Balfanz and Legters 2004). With just under 200,000 students, the district is ninth largest in the United States. The large proportions of poor and minority students in Philadelphia, the predominance of large neighborhood high schools in the city, and the high course failure and dropout rates at neighborhood high schools parallel those of other large-city school districts, including New York, Chicago, Detroit, Houston, Milwaukee, Washington, D.C., and Baltimore. Currently, more than three-quarters of the students in the Philadelphia public schools come from low-income families. About 65 percent of the students are African American; 15 percent are Latino, 5 percent are Asian, and 16 percent are white. Many of the neighborhood high schools are racially segregated and overwhelmingly poor.

\section{DATA AND METHODS}

Our analysis draws on individual-level student record data from the school district for 14,747 first-time freshmen (that is, students who had been $8^{\text {th }}$ graders the previous year) attending Philadelphia public schools during the 1998-99 school year and 23,423 ninth graders (first-time or repeating) during the 1999-00 school year.

Our first analysis, using data for the 1998-99 first-time freshmen,

identifies the predictors of non-promotion to tenth grade. ${ }^{2}$ We examine the 
impact on ninth grade non-promotion of factors knowable from district data when students enter high school, and as a result, we include only those students who attended Philadelphia public schools for both eighth and ninth grade. In so doing, we capture the characteristics of most of the first-time freshmen, since just 10 percent of all ninth graders were new to the district during that year. To identify the predictors of non-promotion, we use logistic regression with the Huber/White estimator of variance, which adjusts for the non-independence of observations that results from students being clustered by school (White 1982). Since some observations were excluded due to missing variables, we treat our data set as a sample from a larger population and use standard inferential statistical methods.

Our second set of analyses uses descriptive data from the subsequent freshman cohort (1999-00) to examine how students with one or more risk factors for non-promotion were distributed across neighborhood high schools.

\section{Variables}

\section{Predictors of non-promotion among 1998-99 first-time freshmen}

For this analysis, we excluded 7 percent of the observations from our initial data set of 14,131 students, either because they had left during the middle of the ninth grade year (making it impossible to determine promotion status) or had stayed through the year but had an unclear promotion status. A multiple imputation technique (MVIS in Stata) was used to impute values for missing 
observations in age, test scores, the number of courses failed in eighth grade, eighth grade attendance, and the number of credits attempted in ninth grade. Table 1 shows the mean, standard deviation (where appropriate), and percent of cases imputed for each variable in the regression. The final data set includes 12,802 students who were first-time freshmen in 1998-99.

Non-promotion to ninth grade. For the analysis of risk factors for nonpromotion among first-time 1998-99 ninth graders, we created a dummy variable that takes the value of 1 if the student was not promoted at the end of the year. To determine promotion status, we examined the grade level for students during the 1998-99 and 1999-00 school years; those who were classified as ninth graders during both years were coded as not promoted. For those students who had missing grade levels in the 1999-00 file (for example, because they dropped out over the summer), we examined the number and type of credits they earned during the 1998-99 year to determine whether they would have been promoted had they remained in school. If we could not determine their promotion status from credit records, they were excluded from the analysis.

Demographic factors. Student race, gender, and date of birth were obtained from school district records. We created a "dummy variable" that takes the value of 1 if a student is over-age for ninth grade - that is, 15 years or older at the start of the freshman year. 
Course failure in eighth grade. To determine whether ninth graders had a history of course failure in middle school, we used the student report card file to create a variable for the number of courses failed in eighth grade. With very few exceptions, students took the same number of courses during eighth grade, so we left the variable as number of courses failed, rather than percent failed, to aid interpretability of the regression coefficient.

Scores on eighth grade standardized tests. Reading and math scale scores on the eighth grade Stanford Achievement Test, $9^{\text {th }}$ edition (SAT-9) were taken from school district records. In order to model possible non-linearity of effects, we created four "dummy" variables for math score and four for reading score corresponding to 1) scoring at the sixth grade equivalent or below; 2) scoring at the seventh grade equivalent; 3) scoring at the eighth grade equivalent; and 4) scoring at the ninth grade equivalent or higher.

Eighth grade attendance rate. To create this variable, we took the total number of days the student attended and divided it by the total number of days he or she was enrolled in the district.

Other variables. Special education status (other than "Mentally Gifted") was obtained from school district records. We also calculated the number of credits attempted in ninth grade, since that could have an impact on credit accumulation and promotion. 
Distribution of risk factors for non-promotion

For this second analysis, we used data from 14,121 first-time freshmen and 9,302 repeating freshmen during the 1999-00 school year. We examine how four key characteristics of ninth graders - repeater status, and for first-time freshmen, age, scores on eighth grade standardized tests, and eighth grade attendance - distribute across the city's high schools. Missing observations were imputed using a multiple imputation technique: 4.2 percent of the observations for age, 7.3 percent of the reading scores, 9 percent of the math scores, and 1.2 percent of the observations for eighth grade attendance were imputed using each of these variables plus scores on the SAT- 9 subtests and the number of courses failed in eighth grade as predictors.

\section{RISK FACTORS FOR NON-PROMOTION}

The regression analysis in Table 2, which includes only students who were first-time freshmen in 1998-99, indicates a number of factors that increase the risk of spending a second year as a ninth grader. Both coefficients and odds ratios are reported in the results.

The are no statistically significant differences in the odds of nonpromotion between African American students (the reference category) and whites, Asians, Latinos, or Native Americans. However, females are less likely than males to be in ninth grade for a second year. 
Notably, students who are over-age - that is, 15 years or older when they enter high school -- are at greater risk of non-promotion, even controlling for previous academic achievement and attendance. The odds of non-promotion are 27 percent greater for students who are 15 or older than they are for younger students.

Higher-achieving students are considerably less likely to experience nonpromotion in ninth grade. In comparison to students who score at the sixth grade level or below in mathematics, those who score at the seventh grade level have odds that are lower by almost a quarter; those at the eighth grade level have odds of non-promotion that are lower by 42 percent in comparison to students at the sixth grade level or below; and those at the ninth grade level or above have odds that are lower by almost 60 percent. A similar phenomenon can be seen with reading scores: students at the eighth or ninth grade levels have decreased odds of non-promotion in comparison to those at the sixth grade level or below. However, there is no statistically significant difference between those with seventh grade reading levels and those who are at sixth grade or below. Notably, both math and reading skills have an independent impact on the odds of being promoted.

Eighth grade academic characteristics of students other than standardized tests also predict non-promotion. Each additional course failed in eighth grade increases the odds of non-promotion in ninth grade by 16 percent, and each one 
percentage-point increase in the eighth grade attendance rate decreases the odds of non-promotion by 4 percent. The effect for receiving special education services approaches statistical significance $(p=.054)$. Even when other academic factors are controlled, special education students have lower odds of nonpromotion. We can only speculate on the reasons for the apparently salutary effect of special education. It may be the case that the difference in academic demands between eighth grade and ninth grade are not as dramatic for special education students as they are for other students. Perhaps there is a positive effect of small, self-contained classes that operates through students coming to know their teachers well and feeling a greater sense of connectedness to school.

Eighth grade attendance is a powerful predictor of non-promotion in ninth grade. Each additional percentage point increase in attendance decreases the odds of repeating ninth grade by 5 percent. Finally, and not surprisingly, the higher the number of credits a student attempted in ninth grade - essentially, the more classes one took - the lower the odds of not being promoted to tenth grade.

\section{THE DISTRIBUTION OF NINTH GRADERS AT-RISK OF NON-}

\section{PROMOTION}

Ninth graders with one or more risk factors for non-promotion are distributed unevenly across the district's high schools. The city's magnet schools, which choose their entering classes on the basis of previous achievement, serve 
relatively low proportions of students who are at-risk for ninth grade failure. In contrast, freshmen who are over-age, have weak academic skills, poor eighth grade attendance, or some combination of these characteristics are typically found in neighborhood high schools. Ninth graders with the greatest educational challenges are not simply concentrated in neighborhood high schools; rather, they predominate, often to an astonishing degree.

\section{First-time freshmen: Academic skill levels}

During the 1999-2000 school year, just 44 percent of the district's firsttime ninth graders performed at least at the seventh grade level in both reading comprehension and mathematics on the Stanford Achievement Test (SAT-9) given at the end of eighth grade. As demonstrated by the data in Table 2, students who are at the seventh grade level or above in math or reading have significantly improved odds of being promoted to tenth grade, in comparison to those with lower scores. Among Philadelphia’s 1998-99 first-time freshmen, the nonpromotion rate for students who scored at the seventh grade level or above on both math and reading was 18 percent, in comparison to 43 percent among their classmates who scored below that level.

Figure 1 provides more detail on the distribution of mathematics and reading comprehension scores on the eighth grade SAT-9 test for first-time freshmen attending neighborhood high schools. In reading comprehension, barely 
a quarter of the incoming freshman class tested at or above grade level (8.7) during eighth grade, and only about 20 percent were at or above grade level in mathematics. In mathematics, another 26 percent scored at the upper elementary level (7-8.6), while the largest proportion of students scored at the fifth and sixth grade levels.

The reading comprehension levels for students at neighborhood high schools are distributed much more evenly than for mathematics. While there were more students reading at less than a fifth grade level than doing mathematics at that level, there were also more students reading above grade level than doing math above grade level. Nevertheless, almost half of the first-time freshmen had reading comprehension levels at the $6^{\text {th }}$ grade level or below.

The intense concentration of students with weak academic skills in neighborhood high schools is shown in Figure 2, which depicts, by high school, the percentage of 1999-00 first-time freshmen who scored at least at the seventh grade level in both math and reading on the SAT-9. Each school is represented by a column, and the city's magnet, vocational, and neighborhood high schools are included for comparison. Students who are in disciplinary schools or schools with other grade configurations - such as a K-12 school - are not included (hence, the smaller $\mathrm{n}$ in comparison to Figure 1). Magnet schools are represented by darker columns and vocational schools by slashed columns. 
Only magnet schools had 80 percent or more of their first-time freshmen reading and doing math at a seventh grade minimum. In contrast, the majority of Philadelphia’s neighborhood high schools had entering freshman classes in which less than 40 percent of the students did as well on both the eighth grade reading comprehension and math sections of the SAT- 9 as the average seventh grader nationally. Only three of the neighborhood high schools had incoming freshman classes where at least half of the students had grade equivalents at the seventh grade level or above on both math and reading.

In an era of higher standards for promotion and graduation, educators and policymakers need to have a deep understanding of the concentration of students with relatively weak academic skills in neighborhood high schools. If appropriate curricula and supports for students are not included in a reform strategy at these schools, increased standards - particularly in terms of mandated college preparatory courses - will likely result in massive student course failure or else a thwarting of the spirit of the standards movement through dilution of course content. In mathematics, for example, ninth graders are increasingly placed in introductory algebra classes during the freshman year, despite skill gaps in fundamental arithmetic. These students typically have mastered computation with whole numbers but have difficulty conceptually and computationally with fractions, decimals, and percents. Yet they encounter Algebra 1 textbooks that typically treat these as topics to be reviewed while developing new skills in 
algebra (Balfanz, McPartland, and Shaw 2002). The organization of the curriculum often does not make space for students to take courses that would allow them to make "catch up" gains, nor are there many curriculum materials that specifically target the spotty skills of urban ninth graders. The sheer number of students with skill gaps means that any extra attention that teachers can give students having trouble with the ninth grade curriculum is necessarily diluted among the many who need assistance.

Likewise, students with weak reading comprehension levels have difficulty in a wide spectrum of classes, where they struggle to comprehend high school texts. These students are less likely to be able to relate material to previous knowledge, examine how subtitles and captions structure a passage, or use context clues to understand unfamiliar vocabulary (Balfanz, McPartland, and Shaw 2002). Their secondary-certified English teachers are generally unprepared to diagnose specific problems that students encounter with reading or to teach reading comprehension strategies, having been educated instead to teach high school level literature and composition. Further, students' social studies and science teachers generally are unfamiliar with techniques to help poor readers draw meaning from text. 


\section{First time freshmen: Age at entrance to high school}

On average, first-time freshmen in Philadelphia’s neighborhood high schools were fourteen-and-a-half years old when they began ninth grade in the 1999-2000 school year. Twenty percent of the first-time freshmen at these schools, however, had already turned fifteen by the time school opened in September. At many of the neighborhood high schools, fully one-quarter of the first-time freshmen were 15 years old or older at the start of ninth grade. At one school, 33 percent of the first-time freshmen were at least fifteen years old.

These students are usually over-age for grade because they have experienced academic difficulty and been retained in grade at some other point in their schooling. However, as demonstrated in Table 2, age is not simply a proxy for weaker academic skills but has an independent effect on the odds of nonpromotion. Controlling for academic characteristics, older students are more likely not to be promoted at the end of ninth grade. Among the 1998-99 first-time freshmen, students who were fourteen years and younger at the start of the school year were not promoted at a rate of 29 percent, a stark contrast to the 47 percent non-promotion rate for those who are 15 years old and older.

If the 15-year-old freshmen were to graduate in four years, many of them would already be 19 years old by the time they received their diplomas. If they were to follow a pattern typical of many neighborhood high school students and take five years to graduate, a large number would be 20 years old by the end of 
their senior year. By that point, most of their age-peers nationally already would have finished a few semesters of college or been in the workplace for several years.

\section{First time freshmen: Eighth grade attendance}

On average, freshmen who entered neighborhood high schools in 1999-00 had attended school 86 percent of the time during eighth grade. Just over half of the students had attended at least 90 percent of the days they were enrolled. But a substantial minority of the students had extremely spotty attendance. Almost 20 percent of the students attended at least half the time but less than 80 percent of the time, meaning that they had missed at least 36 days of school. An additional 3 percent attended less than half the time in eighth grade. In total, then, almost onequarter of the first-time freshmen at neighborhood high schools had missed more than seven weeks of instruction during the previous year.

Freshmen with poor attendance in eighth grade also had, on average, weaker academic skills as measured by the SAT-9. For example, the mean reading comprehension grade equivalent for those with less than 50 percent attendance was 5.5, compared to 7.5 for those who came to school at least 90 percent of the time. Their average age was also higher than the more consistent attenders. Those with less than 50\% attendance were about half a year older, on average, than those who had 90 percent attendance. 
These data highlight the multiple risk factors for non-promotion that characterize a segment of the first-time freshmen at neighborhood high schools, underscoring the challenges that neighborhood school face in meeting the needs of numerous students who have weak academic skills, are over-age, and have a history of inconsistent school attendance. At the same time, the direct effect of poor attendance on non-promotion (net of other academic characteristics) shown in Table 2 suggests that neighborhood high schools need to pay attention to the subgroup of students with weak attendance in the middle grades, regardless of whether they scored well on tests or passed all their classes in eighth grade.

\section{Ninth grade repeaters}

During the 1999-2000 school year, first-time freshmen made up just 60 percent of the ninth graders in Philadelphia's public high schools. The rest of the ninth graders - the ninth grade "repeaters” - had been in high school the year before but had not been promoted to tenth grade. Not only do ninth grade repeaters form a large part of the urban neighborhood high school population, but they are at elevated risk for non-promotion. The non-promotion rate for students repeating ninth grade in 1998-99 was 69 percent, almost twice as high as the 35 percent of first-time freshmen who were not promoted.

The percentage of 1999-2000 ninth graders who were first-time freshmen varied considerably from school to school. At most of the magnet high schools, 
only a handful of ninth graders were repeaters: between 90 and 100 percent of the ninth graders at most of the magnet schools were first-time freshmen. Repeaters made up only a small percentage of the freshman class at magnet schools because magnet students are less likely to earn few credits in the first place and, when they do fail courses, they can be "returned" to their neighborhood high schools the next year. Vocational schools had larger percentages of ninth grade repeaters than magnet schools, but no neighborhood high school had a smaller percentage of repeaters than any vocational school. At most neighborhood schools, which do not have the option to shift repeating ninth graders to another institution, firsttime freshmen formed just a bare majority of the ninth grade class. At several schools, first-time freshmen students comprised less than 50 percent of the ninth graders.

Some of the students who were spending a second year as ninth graders in 1999-2000 missed promotion by a hair, failing one key required course. But our analysis of credits earned indicates that for most of the repeaters, their previous year in ninth grade was an unmitigated academic disaster. During their first year in ninth grade (1998-1999), more than 60 percent of the repeaters accumulated no more than three credits in a district where most freshmen carried a course load of six credits or more. More than a third of the repeaters earned a maximum of one credit, meaning that they essentially "lost" an entire year of high school. At the 
start of the 1999-00 school year, then, most ninth grade repeaters had earned very few high school credits.

At the beginning of the 1999-2000 school year, the average ninth grade repeater in the district was already 16 years old, in sight of the legal schoolleaving age of 17 . Since most repeaters have relatively few credits, it would probably take them at least four more years to earn their high school diploma, even under the most optimistic scenario. If all of the repeaters were to graduate in June 2003, four years after they began ninth grade for the second (or third) time, about 60 percent would have been 19 or 20 years old at graduation, well past the age of the typical high school senior. Almost one-quarter would have been at least 21 years old when they earned their diplomas.

Academic outcomes for most repeaters do not significantly improve during their additional year in ninth grade. Students repeating ninth grade in 1999-2000 who did not drop out of school passed on average only about 50 percent of their classes during that year, and those who had earned three or fewer credits during the previous school year fared even worse, passing 40 percent of the courses in which they were enrolled. In comparison, first-time freshmen during 1999-2000 passed, on average, 75 percent of their classes.

It is important to keep in mind that the sheer number of ninth grade repeaters in Philadelphia's public schools - and by extension, in other large-city school districts - is quite large. Approximately 4500 of Philadelphia's ninth grade 
repeaters—enough to fill three medium-size high schools--had earned no more than three credits during the previous school year, making them prime candidates for taking at least an additional four years to graduate.

\section{The extreme concentration of educational need at neighborhood high schools}

When some of the factors associated with ninth grade failure - having already repeated ninth grade, being older at the start of ninth grade, and having weaker academic skills - are aggregated at the school level, the magnitude of the challenge facing educators at urban neighborhood high schools becomes painfully clear. At most of the neighborhood high schools, the proportion of freshmen without any risk-factors for non-promotion is extremely low.

\section{Figure 3 about here}

Figure 3 presents this challenge graphically for each of the high schools.

All of the students who were first-time freshmen or repeating ninth graders during the 1999-2000 school year are represented in the graph. Students who were new to the district are not included in this graph since we have no information on their repeater status or academic skill level. Data for each individual school can be connected with a vertical line. The top horizontal line represents the proportion of students who were first-time freshmen. The second horizontal line indicates the proportion who were first-time freshmen and on-age (that is, no more than 14 years old). The first (grey) column for each school indicates the percent of 
students who were first-time freshmen, on-age, and had attendance of at least 80 percent in eighth grade (a low bar for "good” attendance, we argue). The second (slashed) column for each school indicates those who were first-time ninth graders, on-age, had at least 80 percent attendance in eighth grade, and were at

least at the $7^{\text {th }}$ grade level in math and reading. Had we plotted the percentage of students who were all of the above plus at least on grade level in both math and reading, the percentage of these students at most of the neighborhood high schools would be so miniscule as to be barely visible on a graph.

In the magnet schools, students at low risk for ninth grade academic trouble clearly predominated. In contrast, the majority of the 22 neighborhood high schools had ninth grade classes in which less than 20 percent of the ninth graders were first-time freshmen, on-age, and no more than two years below grade level in reading and math. At neighborhood high schools with the highest proportions of at-risk students, only about 10 percent of the ninth graders were in this relatively lower-risk category. Ninth graders who were first-timers, on-age, and no more than two years behind grade level in math and reading were a tiny elite at most of the neighborhood high schools.

\section{CONCLUSION}

In the past decade, efforts to improve the high school experience for students in big-city school systems have centered on creating alternatives to large 
neighborhood high schools. Despite the growth of alternatives, the majority of students in large cities conclude their public schooling in large neighborhood high schools, many of which are characterized by dismal academic outcomes. Further, it is very likely that neighborhood high schools will dominate the educational landscape in central cities in both the near and medium term. The relatively short reach of small-schools projects suggests that it remains imperative to transform the educational experiences of students who will continue to attend high-poverty neighborhood high schools.

An essential step in transforming that experience, we argue, is developing a deep understanding the kinds of academic challenges that students bring with them when they enter high school, how those challenges are concentrated within particular schools, and the level of resources needed for schools that have large proportions of students with one or more characteristics placing them at risk for course failure and high school dropout. In our experience, many high schools, districts, state policymakers, education researchers, and school reform programs have lacked specific knowledge of the scale of need at neighborhood high schools. Without an understanding of the nature of this need, reform proposals are very likely to be insufficient or off-target. An example of an insufficient reform would be one that mandates that all ninth graders must pass Algebra 1 in order to be promoted to tenth grade but provides no ideas or additional resources to schools that would allow them to teach algebra to students who entered with 
math skills at the fifth or sixth grade level. The result of such mandates is likely to be either math classes that are "algebra" in name only or frustrated teachers and high percentages of students who have failed a required class.

A major reason for the misconceptions about what it takes to improve neighborhood high schools is that a wide range of data at the individual school level is not readily available to policymakers, researchers, or even the principals and teachers who work in these schools. Most of the published federal data on schools use the school district as the lowest level of aggregation. School-level data are available in a "report card" form in most states, but these reports typically include just a few key accountability measures rather than a detailed analysis of the characteristics of students attending each school. Moreover, urban school districts often lack the infrastructure to provide their high schools with detailed data on student composition and educational progress on a timely basis. As a result, critical data about the "educational demographics” of the student population in neighborhood high schools - for example, the number of students who have spent two or more years in ninth grade, the average reading or mathematics level of entering freshmen, or the number of students who are overage for their grade - are often only guessed at.

Getting to know the students is a task that must be carried out by each individual high school and district. While the overwhelming message from this analysis of Philadelphia's neighborhood high schools is one of immense need, 
there is also variation within this group of schools. Some schools have historically had very large percentages of ninth grade repeaters. Some serve students with extremely low skills; others have students who are not as far behind the national average. A few high schools have large percentages of entering freshmen who have been failing courses for years and would not have been promoted except for a district policy that permits retaining students only once prior to high school. Each of these types of students will require a different strategy to help them succeed in ninth grade, and high schools will need to tailor their strategies to the different groups of students they serve.

Finally, policymakers and researchers need to pay more attention to educational demographics at the school level in order to understand and then advocate for the level of educational and financial resources necessary to turn around neighborhood high schools. The data that we have presented show that there are numerous high schools in Philadelphia - and by extension, in large cities across the country - where almost every student has one or more risk factors for course failure, non-promotion, and dropping out. Yet, as a group, these neighborhood high schools receive no special federal resources over and above limited Title I dollars to face educational challenges of almost staggering proportions. In order to provide all students with the high schooling they will require to succeed, large and sustained investments of human and financial capital must be made in schools that serve primarily, and often almost exclusively, 
students with multiple risk factors for failure. Identifying these schools and detailing the scale and scope of their needs is just the first step in the longoverdue task of improving the educational experience of the vast majority of urban high school students. 


\section{References}

Alliance for Excellent Education. (2001). Investing in Excellence: Making Title I Work for All Children. Washington, D.C.: Alliance for Excellent Education.

Balfanz, R. \& Legters, N. (2004). Locating the Dropout Crisis. Baltimore: Center for Social Organization of Schools, Johns Hopkins University.

Balfanz, R., McPartland, J., \& Shaw, A. (2002). Re-conceptualizing Extra Help for High School Students in a High Standards Era. Paper presented at the Preparing For America’s Future High School Symposium, Office of Adult and Vocational Education, U.S. Department of Education, Washington, D.C.

Brooks-Gunn, J. \& Duncan, G. (1997). The Effects of Poverty on Children. The Future of Children, 7, 55-71.

Chester, M., Offenberg, R. \& Xu, M. (2001, April). Urban Teacher Transfer: A Four Year Cohort Study of the School District of Philadelphia Faculty. Paper presented at the meetings of the American Educational Research Association, Seattle.

City KIDS COUNT: Data on the Well-being of Children in Large Cities. (1990).

Baltimore: Annie E. Casey Foundation.

Consortium on Chicago School Research. (2002). Personal communication. 
Council of Great City Schools. (1998). Adequate State Financing of Urban Schools: Part I, An Analysis of Funding to the Philadelphia Public Schools. Washington, D.C.: Council of Great City Schools.

Fine, M. (1994). Chartering Urban School Reform. In M. Fine (Ed.), Chartering Urban School Reform (pp. 5-30). New York: Teachers College Press.

Hassell, B. (1999). The Charter School Challenge. Washington, DC: Brookings. Hill, P. (2000). It Takes a City: Getting Serious about Urban School Reform. Washington, D.C.: Brookings.

Kane, P. R. (2000). The Difference between Charter Schools and Charterlike Schools. In D. Ravitch \& J. Viteritti (Eds.), City Schools: Lessons from New York (pp. 65-88). Baltimore: Johns Hopkins.

Kasarda, J. (1993). Cities as Places Where People Live and Work: Urban Change and Neighborhood Distress. In H. Cisneros (Ed.), Interwoven destinies: Cities and the nation (pp. 81-124)). New York: W.W. Norton. Legters, K., Balfanz, R., Jordan, W., \& McPartland, J. (2002). Comprehensive Reform for Urban High Schools: A Talent Development Approach. New York: Teachers College Press.

Moore, D. \& Davenport, S. (1990). School Choice: The New Improved Sorting Machine. In W. Boyd \& H. Walberg (Eds)., Choice in Education: Potential and Problems (pp. 187-223). Berkeley: CA: McCutchan Press Berkeley, CA: McCutchan. 
Neild, R. (2004). “The Effects of Magnet Schools on Neighborhood High Schools: An Examination of Achievement Among Entering Freshmen.” Journal of Education for Students Placed At Risk, 9, 1-21.

Neild, R. C., Stoner-Eby, S. \& Furstenberg, F. (2001). Connecting Entrance and Departure: The Ninth Grade Transition and High School Dropout. Paper presented at the "Dropouts in America” conference, Harvard University. Orfield, G. \& Kornhaber, M.L. (Eds.). (2001). Raising Standards or Raising Barriers?: Inequality and High-Stakes Testing in Public Education. New York: Century Foundation Press.

Peterson, P. (1991). “The Urban Underclass and the Poverty Paradox.” In C. Jencks \& P. Peterson (Eds.), The Urban Underclass (pp. 3-27). Washington, D.C.: Brookings.

Philadelphia Education Fund. (2001). Teacher Staffing in the School District of Philadelphia: A Report to the Community. Philadelphia: The Philadelphia Education Fund.

Riehl, C., Pallas, A. \& Natriello, G. (1999). Rites and Wrongs: Institutional Explanations for the Student Course-scheduling Process in Urban High Schools. American Journal of Education, 107, 116-154.

Roderick, M. (1993). The Path to Dropping Out: Evidence for Intervention. Westport, CT: Auburn House. 
Roderick, M. \& Camburn, E. (1999). Risk and Recovery from Course Failure in the Early Years of High School. American Educational Research Journal, 36, 303-343.

White, H. (1982). Maximum likelihood estimation of misspecified models. Econometrica, 50, 1-25.

Wilson, W.J. (1987). The Truly Disadvantaged. Chicago: The University of Chicago Press.

Witte, J. (2001). The Market Approach to Education: An Analysis of America's First Voucher Program. Princeton, NJ: Princeton University Press. 


\section{Table 1}

\section{Description of variables used in Table 2}

\begin{tabular}{|c|c|c|c|c|}
\hline & Range & Mean & $\begin{array}{l}\text { Standard } \\
\text { deviation }\end{array}$ & $\begin{array}{l}\text { Percent } \\
\text { imputed }\end{array}$ \\
\hline African American & $0-1$ & .64 & $\mathrm{n} / \mathrm{a}$ & 0 \\
\hline Asian & $0-1$ & .05 & $\mathrm{n} / \mathrm{a}$ & 0 \\
\hline Latino & $0-1$ & .11 & $\mathrm{n} / \mathrm{a}$ & 0 \\
\hline White & $0-1$ & .20 & $\mathrm{n} / \mathrm{a}$ & 0 \\
\hline Female & $0-1$ & .50 & $\mathrm{n} / \mathrm{a}$ & 0 \\
\hline Age 15 or older at the start of school year & $0-1$ & .20 & $\mathrm{n} / \mathrm{a}$ & $3.5 \%$ \\
\hline \multicolumn{5}{|l|}{$8^{\text {th }}$ grade academic characteristics } \\
\hline Number of courses failed, 8th grade & $0-6$ & .44 & 1.06 & $9.6 \%$ \\
\hline Percent of days attended, $8^{\text {th }}$ grade & $0-100$ & 87.5 & 13.6 & $.59 \%$ \\
\hline Math equivalent is $7^{\text {th }}$ grade & $0-1$ & .17 & $\mathrm{n} / \mathrm{a}$ & $7.6 \%$ \\
\hline Math equivalent is $8^{\text {th }}$ grade & $0-1$ & .09 & $\mathrm{n} / \mathrm{a}$ & $7.6 \%$ \\
\hline Math equivalent is $9^{\text {th }}$ grade & $0-1$ & .28 & $\mathrm{n} / \mathrm{a}$ & $7.6 \%$ \\
\hline Reading equivalent is $7^{\text {th }}$ grade & $0-1$ & .15 & $\mathrm{n} / \mathrm{a}$ & $5.7 \%$ \\
\hline Reading equivalent is $8^{\text {th }}$ grade & $0-1$ & .12 & $\mathrm{n} / \mathrm{a}$ & $5.7 \%$ \\
\hline Reading equivalent is $9^{\text {th }}$ grade & $0-1$ & .31 & $\mathrm{n} / \mathrm{a}$ & $5.7 \%$ \\
\hline \multicolumn{5}{|l|}{$9^{\text {th }}$ grade academic characteristics } \\
\hline $\begin{array}{l}\text { Received special education in } 9^{\text {th }} \text { grade } \\
\text { Number of course credits attempted in 9th } \\
\text { grade }\end{array}$ & $.25-14.25$ & 6.67 & 1.53 & $5.9 \%$ \\
\hline
\end{tabular}




\section{Table 2}

\section{Predictors of ninth grade non-promotion using logistic regression with robust standard errors}

$b \quad$ se $\exp (B)$

\section{Demographic characteristics}

White

$\begin{array}{lll}-.05 & .12 \quad .96\end{array}$

Asian

$-.24 \quad .15 \quad .78$

Latino

.13

$.18 \quad 1.14$

Native American

$-.50 \quad .47 \quad .60$

Female

$-.26 * * * \quad .06$

$.77 * * *$

Age at start of school year

$.24 * * *$

.06

$1.27 * *$

$\mathbf{8}^{\text {th }}$ grade academic characteristics

Math grade equivalent is $7^{\text {th }}$ grade

Math grade equivalent is $8^{\text {th }}$ grade Math grade equivalent is $9^{\text {th }}$ grade or above

$\begin{array}{lll}-.32 * * * & .07 & .73 * * * \\ -.52 * * * & .08 & .59 * * * \\ -.89 * * * & .09 & .42 * * * \\ -.14 & .08 & .87 \\ -.29 * * & .09 & .75 * * \\ -.63^{* * *} & .09 & .53^{* * *} \\ .15^{* * *} & .03 & 1.16 * * * \\ -.05 * * * & .004 & .96 * * *\end{array}$

$\mathbf{9}^{\text {th }}$ grade academic characteristics

Received special education in $9^{\text {th }}$ grade

$\begin{array}{lll}-.21 & .11 & .81\end{array}$

Number of course credits attempted in 9th grade

$\begin{array}{lll}-.25 * * * & .04 & .78^{* * *}\end{array}$

Constant

$5.44 * * * \quad .48$

Observations

12,802

Pseudo R-square 


\section{Figure 1}

Eighth grade mathematics and reading comprehension grade equivalents (SAT-9): First time freshmen in neighborhood high schools, 1999-200

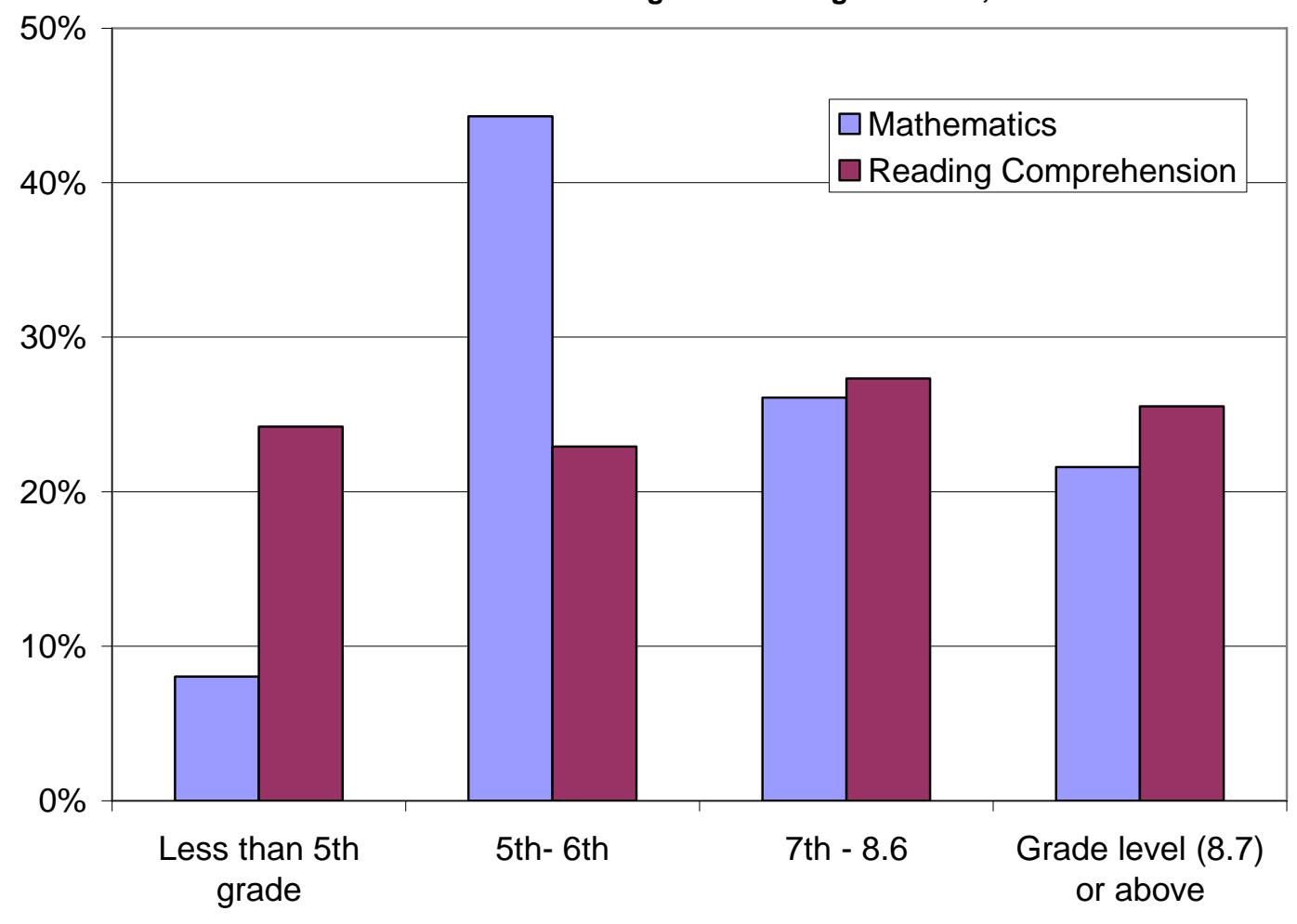

$n=14,120$ 
Figure 2

Percentage of first time freshmen with mathematics and reading comprehension scores at or above the 7th grade level, by high school, 1999-2000

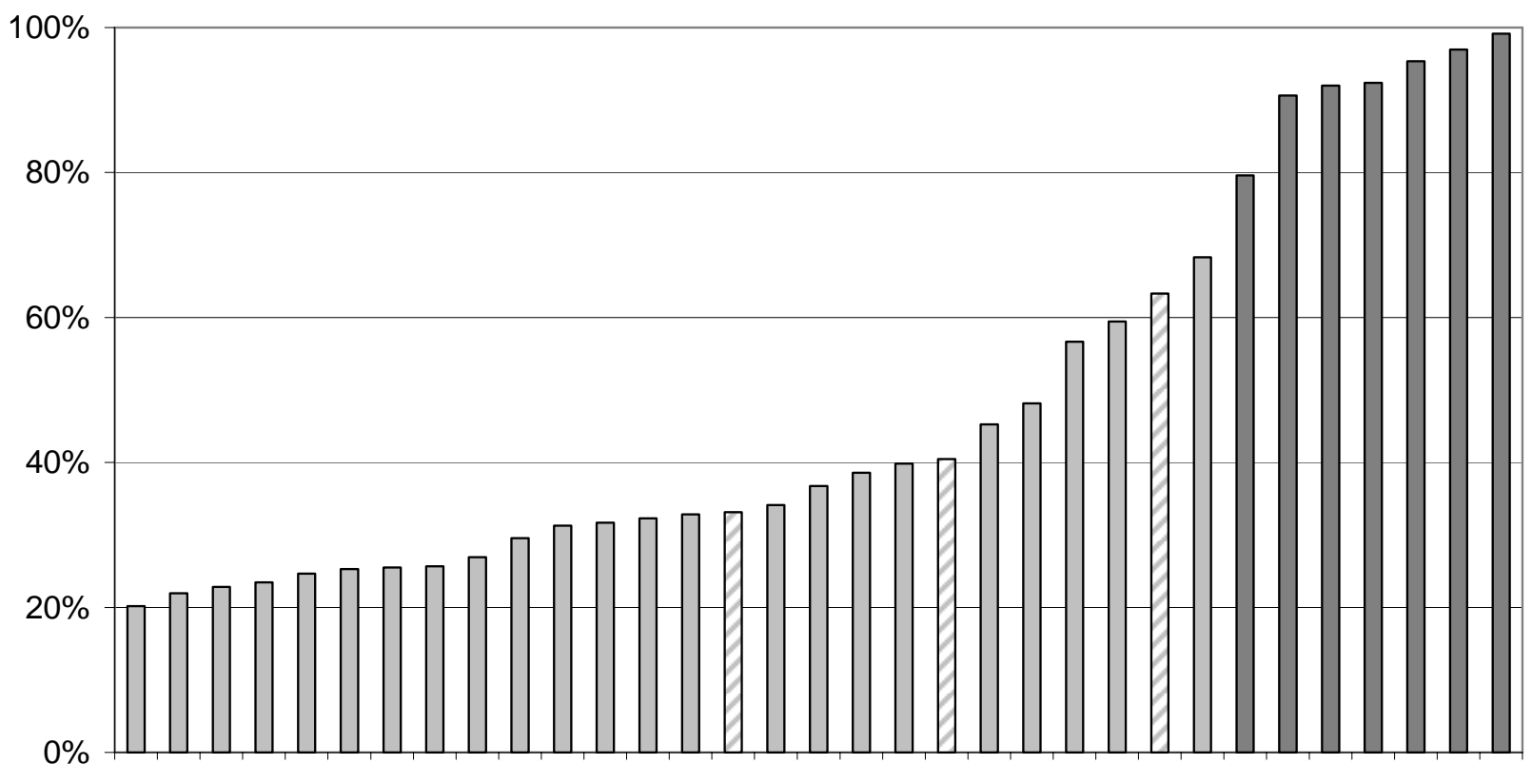

High Schools

$n=12,891$

Magnet high schools

Neighborhood high schools

Vocational high schools 
Figure 3

\section{Percentages of freshmen with various characteristics, by high school, 1999-2000}

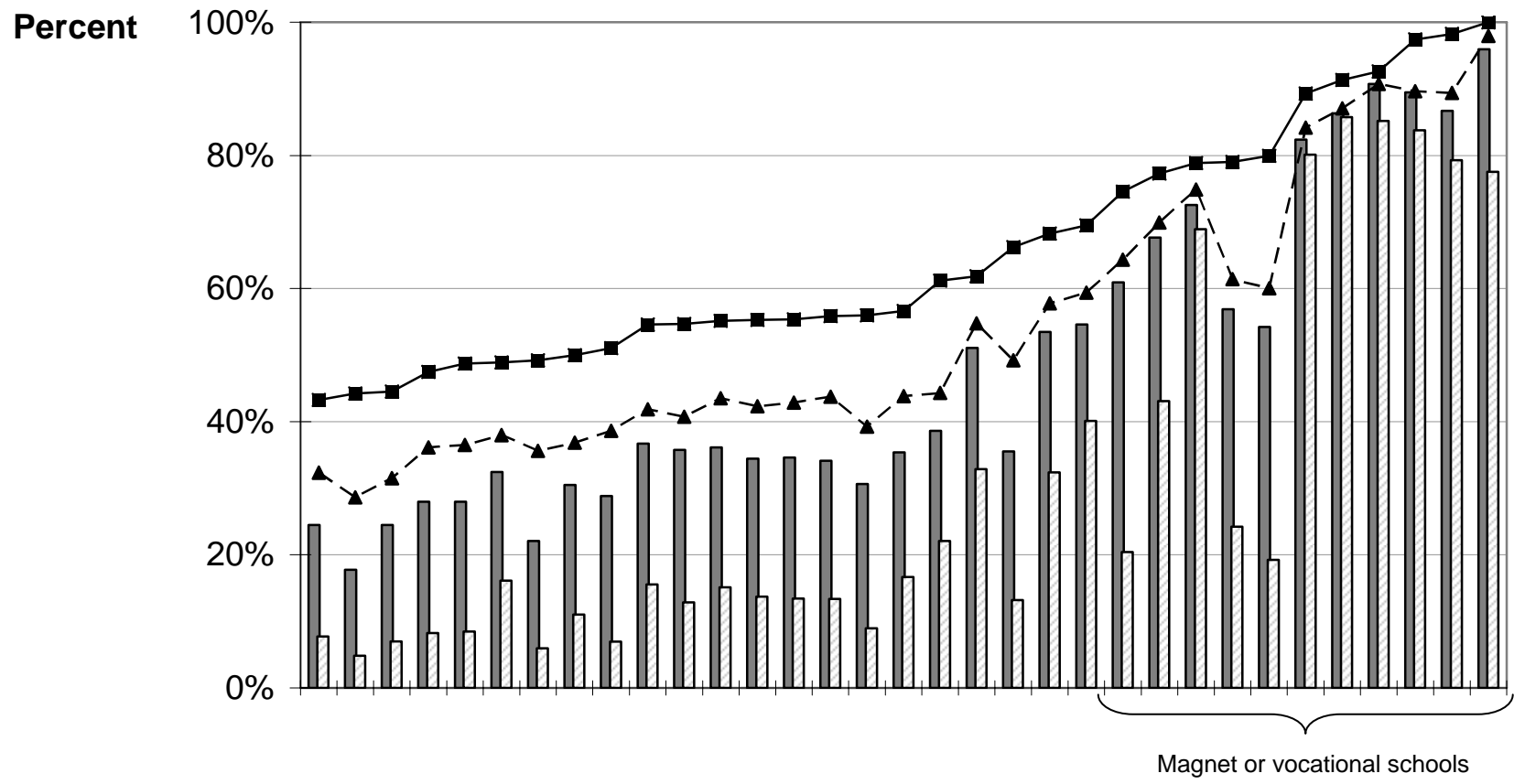

$n=21,876$

- First-time freshmen

First-time, no more than 14 years old

First-time, on-age, attendance of at least $80 \%$ in $8^{\text {th }}$ grade

First-time, on-age, at least $80 \%$ attendance, $7^{\text {th }}+$ in math and reading 



\footnotetext{
${ }^{1}$ The KIDS count data book, published by the Annie E. Casey Foundation, defines a distressed neighborhood as one which has all of the following characteristics: a high poverty rate (above $24.7 \%$ ), a high percentage of female-headed families (above 36.8\%), a high percentage of males unattached to the labor force (above 45.4\%), and a high percentage of families receiving public assistance (above 17.6\%). These figures represent one standard deviation above the mean for all census tracts.

${ }^{2}$ We use the 1998-99 cohort to establish the predictors of non-promotion to $10^{\text {th }}$ grade because a) our most complete data on non-promotion are from that cohort and $b$ ) there were no major initiatives or changes in the district from 1998-99 to 1999-00 that would lead us to believe that the predictors had changed in important ways.
} 